\title{
New WHO Classification of Endometrial Hyperplasias
}

\author{
Neue WHO-Klassifikation der Endometriumhyperplasien
}

Authors

Affiliation
G. Emons ${ }^{1}$, M. W. Beckmann ${ }^{2}$, D. Schmidt ${ }^{3}$, P. Mallmann ${ }^{4}$, for the Uterus commission of the Gynecological Oncology Working Group (ACO)

${ }^{1}$ Department of Obstetrics and Gynecology, University of Göttingen, Göttingen

${ }^{2}$ Department of Obstetrics and Gynecology, University of Erlangen, Erlangen

${ }^{3}$ MVZ Pathology Mannheim, Mannheim

${ }^{4}$ Department of Obstetrics and Gynecology, University of Cologne, Cologne
Deutschsprachige Zusatzinformationen online abrufbar unter: www.thieme-connect.de/ ejournals/toc/gebfra
Bibliography

Dol http://dx.doi.org/

10.1055/s-0034-1396256

Geburtsh Frauenheilk 2015; 75 :

135-136 @ Georg Thieme

Verlag KG Stuttgart · New York .

ISSN 0016-5751

\section{Correspondence}

Prof. Dr. med. Günter Emons

Universitäts-Frauenklinik

Robert-Koch-Straße 40

37075 Göttingen

emons@med.uni-goettingen.de
Endometrioid endometrial carcinoma, the most common form of endometrial cancer, usually develops out of a typical sequence of endometrial hyperplasias. The underlying cause of these hyperplasias is a relative predominance of estrogen combined with insufficient progesterone levels. Typical causes include corpus luteum insufficiency/anovulatory cycles (premenopause), polycystic ovary syndrome and obesity with metabolic syndrome (aromatase conversion of ovarian androgens in adipose tissue), inappropriate hormone therapy post menopause (insufficient dosage of gestagens) or an estrogen or androgen-producing tumor [1].

Even in patients with Lynch syndrome (formerly known as HNPCC), tumorigenesis of hereditary endometrioid carcinoma usually follows the usual progression with development of the respective hyperplasias [1].

Up to now, the correct clinical evaluation of endometrial hyperplasias was made more difficult by the different classification systems still in use: in Germany hyperplasias are sometimes still differentiated according to the classification "glandular-cystic hyperplasia" and "adenomatous hyperplasia grade I to III". In 1994, the WHO classified endometrial hyperplasias into 4 categories:

1. simple hyperplasia without atypia,

2. complex hyperplasia without atypia,

3. simple atypical hyperplasia,

4. complex atypical hyperplasia [1,2].

While categories 1,2 and 4 were generally accepted, pathologists continued to debate the existence of group 3-type hyperplasias. Hyperplasias without atypia (categories 1 and 2) are considered benign pathologies which will regress with conservative treatment (oral gestagens, gestagen IUD, elimination of the cause of anovulation/corpus luteum insufficiency) [1]. A large percentage (up to 60\%) [3] of atypical endometrial hyperplasias (categories 3 and 4) are found to be coexistent with invasive endometrial carcinoma or develop into invasive endometrial carcinoma within the space of just a few years $[1,2,4]$. Hysterectomy (total hysterectomy, not supracervical hysterectomy!) is therefore the treatment of choice for atypical endometrial hyperplasia [4] or - in selected patients, i.e. younger patients wanting to have children - high-dose gestagen therapy with appropriate close histological monitoring $[1,4]$.

The WHO classification of 1994 and even more so the parallel use of the older classification system led to confusion among clinicians. The consequence of this was inadequate diagnosis, with hysterectomies performed for hyperplasias without atypia or gestagens administered in HRT dosages for atypical hyperplasia. Pathologists also experienced difficulties with categorization. This was made even more difficult by the development and parallel use of a further classification system: benign hyperplasia and endometrial intraepithelial neoplasia (EIN) [2].

In its latest classification [5] published in 2014, the WHO has clarified the matter: it now only differentiates between 2 categories of endometrial hyperplasia:

1. hyperplasia without atypia

2. atypical hyperplasia/endometrioid intraepithelial neoplasia ( $\bullet$ Table 1 ).

This reduction to 2 categories was not only due to the need to do away with the confusing multitude of terms currently in use. Rather, it reflects a new understanding of molecular genetic changes.

Hyperplasias without atypia exhibit no relevant genetic changes. They are benign changes and will regress again after the endocrine milieu (physiological gestagen levels) has normalized. In a few cases $(1-3 \%)$, progression to invasive disease may occur if the endocrine disorder (long-term estrogen dominance or relative or absolute gestagen deficiency) persists over the long term. Atypical endometrial hyperplasias exhibit many of the mutations typical for invasive endometrioid endometrial cancer [7]. In up to $60 \%$ of 
Table 1 New WHO classification of endometrial hyperplasias [5].

\begin{tabular}{|c|c|c|c|c|}
\hline New term & Synonyms & Genetic changes & $\begin{array}{l}\text { Coexistent invasive } \\
\text { endometrial carci- } \\
\text { noma }\end{array}$ & $\begin{array}{l}\text { Progression } \\
\text { to invasive } \\
\text { carcinoma }\end{array}$ \\
\hline $\begin{array}{l}\text { Hyperplasia without } \\
\text { atypia }\end{array}$ & $\begin{array}{l}\text { Benign endometrial hyperplasia; simple } \\
\text { non-atypical endometrial hyperplasia; } \\
\text { complex non-atypical endometrial hy- } \\
\text { perplasia; simple endometrial hyperpla- } \\
\text { sia without atypia; complex endometrial } \\
\text { hyperplasia without atypia }\end{array}$ & $\begin{array}{l}\text { Low level of somatic mutations in } \\
\text { scattered glands with morphology on } \\
\text { HE staining showing no changes }\end{array}$ & $<1 \%$ & RR: $1.01-1.03$ \\
\hline $\begin{array}{l}\text { Atypical hyperplasia/ } \\
\text { endometrioid intra- } \\
\text { epithelial neoplasia }\end{array}$ & $\begin{array}{l}\text { Complex atypical endometrial hyperpla- } \\
\text { sia; simple atypical endometrial hyper- } \\
\text { plasia; endometrial intraepithelial neo- } \\
\text { plasia (EIN) }\end{array}$ & $\begin{array}{l}\text { Many of the genetic changes typical for } \\
\text { endometrioid endometrial cancer are } \\
\text { present, including: micro satellite insta- } \\
\text { bility; PAX2 inactivation; mutation of } \\
\text { PTEN, KRAS and CTNNB1 ( } \beta \text {-catenin) }\end{array}$ & $\begin{array}{l}25-33 \%[5] \\
59 \%[3]\end{array}$ & RR: $14-45$ \\
\hline
\end{tabular}

cases, patients have coexisting invasive cancer or are at extremely high risk of developing invasive cancer ( $\bullet$ Table $\mathbf{1}$ ).

The implications for treatment are obvious: hyperplasias without atypia should generally be treated conservatively (normalization of the cycle through weight loss, metformin; oral contraceptives; cyclical gestagens; gestagen IUD). Preventive hysterectomy should only be considered in exceptional cases (e.g., extreme obesity without any prospect of weight loss) $[1,4]$. The surgery should be done as a total hysterectomy, i.e., it must include removal of the cervix [4].

Treatment of atypical hyperplasia/endometrioid intraepithelial neoplasia should generally consist of total (not supracervical) hysterectomy $[1,4]$. Conservative treatment with high-dose gestagens and close histological monitoring should only be considered in exceptional cases (when the patient wants to have children, satisfactory compliance) $[1,4,6]$.

\section{Conclusion}

$\nabla$

The new WHO classification represents an important simplification for clinical practice, particularly with regard to the choice of treatment. Until the new classification comes into general use it would be useful if histological findings include both the new and the previous WHO classification.

\section{References}

1 Kommission Uterus der Arbeitsgemeinschaft Gynäkologische Onkologie e.V. Interdisziplinäre S2k-Leitlinie für die Diagnostik und Therapie des Endometriumkarzinoms. In: Kommission Uterus der Arbeitsgemeinschaft Gynäkologische Onkologie e.V. in der Deutschen Gesellschaft für Gynäkologie und Geburtshilfe e.V. sowie in der Deutschen Krebsgesellschaft e.V., Hrsg. Leitlinien zum Zervixkarzinom, zum Endometriumkarzinom und zu den Trophoblasttumoren. München: W. Zuckschwerdt Verlag; 2008: 73-126

2 Owings RA, Quick CM. Endometrial intraepithelial neoplasia. Arch Pathol Lab Med 2014; 138: 484-491

3 Antonsen SL, Ulrich L, Hogdall C. Patients with atypical hyperplasia of the endometrium should be treated in oncological centers. Gynecol Oncol 2012; 125: 124-128

4 Trimble CL, Method M, Leitao $M$ et al. Management of endometrial precancers. Obstet Gynecol 2012; 120: 1160-1175

5 Zaino R, Carinelli SG, Ellenson LH et al. Tumours of the uterine Corpus: epithelial Tumours and Precursors. In: Kurman RJ, Carcanglu ML, Herrington CS, Young RH, eds. WHO Classification of Tumours of female reproductive Organs. 4th ed. Lyon: WHO Press; 2014: 125-126

6 Kommission Uterus der Arbeitsgemeinschaft Gynäkologische Onkologie e. V. Empfehlungen für die Diagnostik und Therapie des Endometriumkarzinoms. Aktualisierte Empfehlungen der Kommission Uterus auf Grundlage der S2k Leitlinie (Version 1.0, 01.06.2008) ohne Angabe der Evidenzlevel und Empfehlungsgrade (April 2013). Online: www. ago-online.org; last access: 01.01.2015

7 Kandoth C, Schultz N, Cherniack AD et al.; Cancer Genome Atlas Research Network. Integrated genomic characterization of endometrial carcinoma. Nature 2013; 497: 67-73 